\title{
Correction to: Buthionine sulfoximine sensitizes antihormone-resistant human breast cancer cells to estrogen-induced apoptosis
}

\author{
Joan S. Lewis-Wambi ${ }^{1}$, Helen R. Kim ${ }^{1}$, Chris Wambi ${ }^{3}$, Roshani Patel ${ }^{2}$, Jennifer R. Pyle ${ }^{1}$, Andres J. Klein-Szanto ${ }^{4}$ \\ and V. Craig Jordan ${ }^{1 *}$
}

\section{Correction}

After the publication of this work [1] an error was noticed in Fig. 3a and Fig. 5a. In Fig. 3a, the TUNEL staining image for the E2-treated MCF-7:2A cells was accidentally duplicated for the image for the BSO-treated MCF-7:2A cells. We have repeated this experiment using the Click-it-TUNEL kit under the same conditions previously described in our original publication [1] and our results are consistent. Our revised Fig. 3a showed that BSO treatment significantly enhanced E2-induced apoptosis in anti-hormone-resistant MCF-7:2A breast cancer cells compared to E2 or BSO treatment alone, however, in wild-type MCF-7 cells BSO treatment did not significantly alter the growth of these cells either alone or in combination with E2. The corrected Fig. 3a is shown below. Similarly, we also noticed an error in the Western blot shown in Fig. 5a. Specifically, there was a duplication of the phospho-JNK blot for the MCF-7 cells and MCF-7:2A cells for the control, E2, and BSO-treated groups (top blot). To correct this error, we repeated this experiment using the same conditions described in our original publication [1] and the revised Fig. 5a is shown below. We found that BSO combined with E2 dramatically increased phospho-JNK, phospho-c-Jun, and c-Jun expression in MCF-7:2A cells but not in wild-type MCF-7 cells which is consistent with our previous findings in our original publication [1]. Our revisions validate our previous findings and are consistent with the conclusions stated in our original publication. We apologize for these two errors.

\section{Author details}

${ }^{1}$ Department of Medical Sciences, Fox Chase Cancer Center, 333 Cottman Avenue, Philadelphia, PA 19111, USA. ${ }^{2}$ Department of Surgical Oncology, Fox Chase Cancer Center, Philadelphia, USA. ${ }^{3}$ Department of Radiation Oncology, University of Pennsylvania, Philadelphia, USA. ${ }^{4}$ Department of Pathology, Fox Chase Cancer Center, Philadelphia, USA.

Received: 14 May 2018 Accepted: 14 May 2018

Published online: 14 June 2018

\section{Reference}

1. Lewis-Wambi JS, Kim HR, Wambi C, Patel R, Pyle JR, Klein-Szanto AJ, Jordan VC. Buthionine sulfoximine sensitizes antihormone-resistant human breast cancer cells to estrogen-induced apoptosis. Breast Cancer Res. 2008;10:R104.

\footnotetext{
* Correspondence: v.craig.jordan@fccc.edu

1 Department of Medical Sciences, Fox Chase Cancer Center, 333 Cottman

Avenue, Philadelphia, PA 19111, USA

Full list of author information is available at the end of the article
}

(c) The Author(s). 2018 Open Access This article is distributed under the terms of the Creative Commons Attribution 4.0 International License (http://creativecommons.org/licenses/by/4.0/), which permits unrestricted use, distribution, and reproduction in any medium, provided you give appropriate credit to the original author(s) and the source, provide a link to the Creative Commons license, and indicate if changes were made. The Creative Commons Public Domain Dedication waiver (http://creativecommons.org/publicdomain/zero/1.0/) applies to the data made available in this article, unless otherwise stated. 


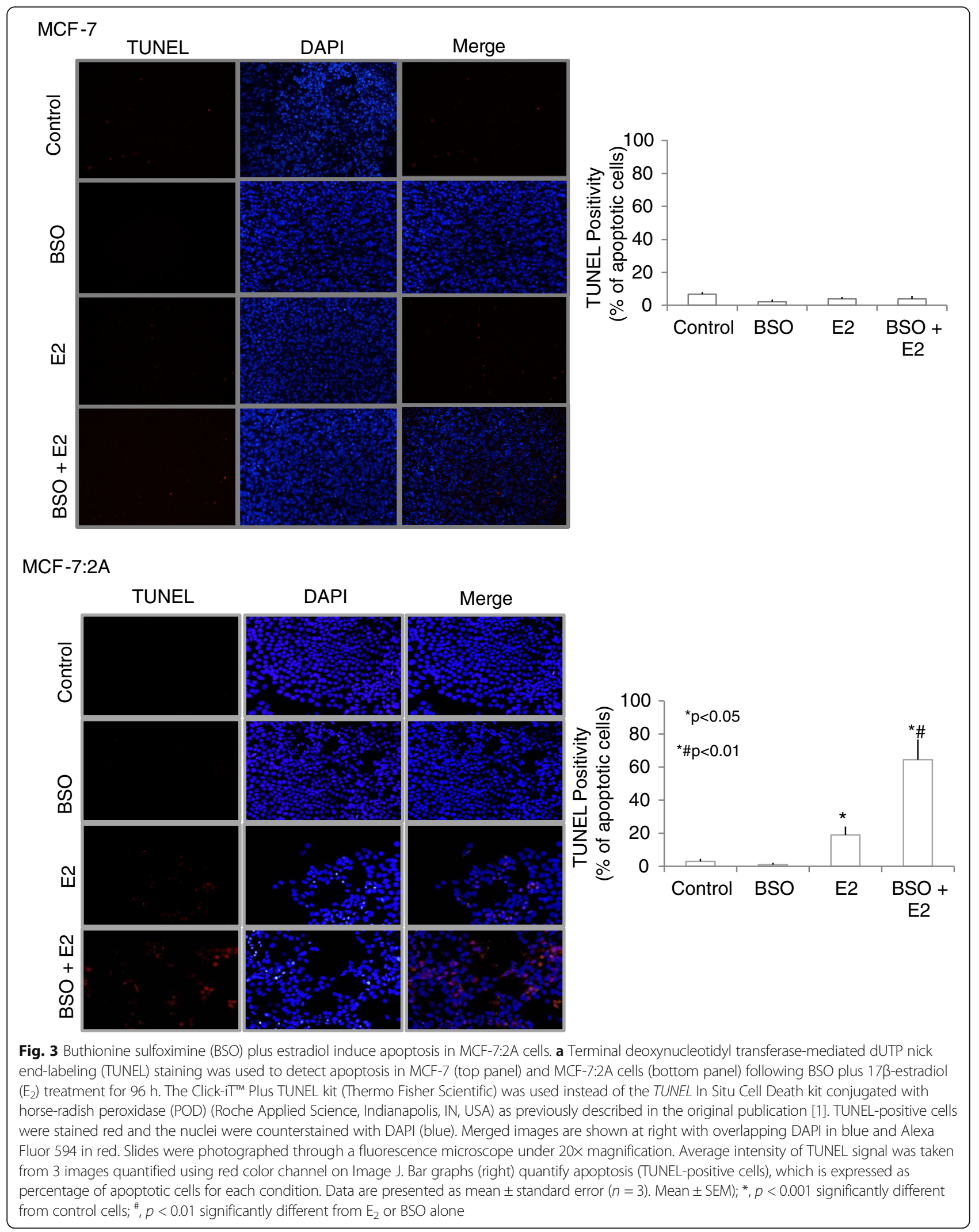




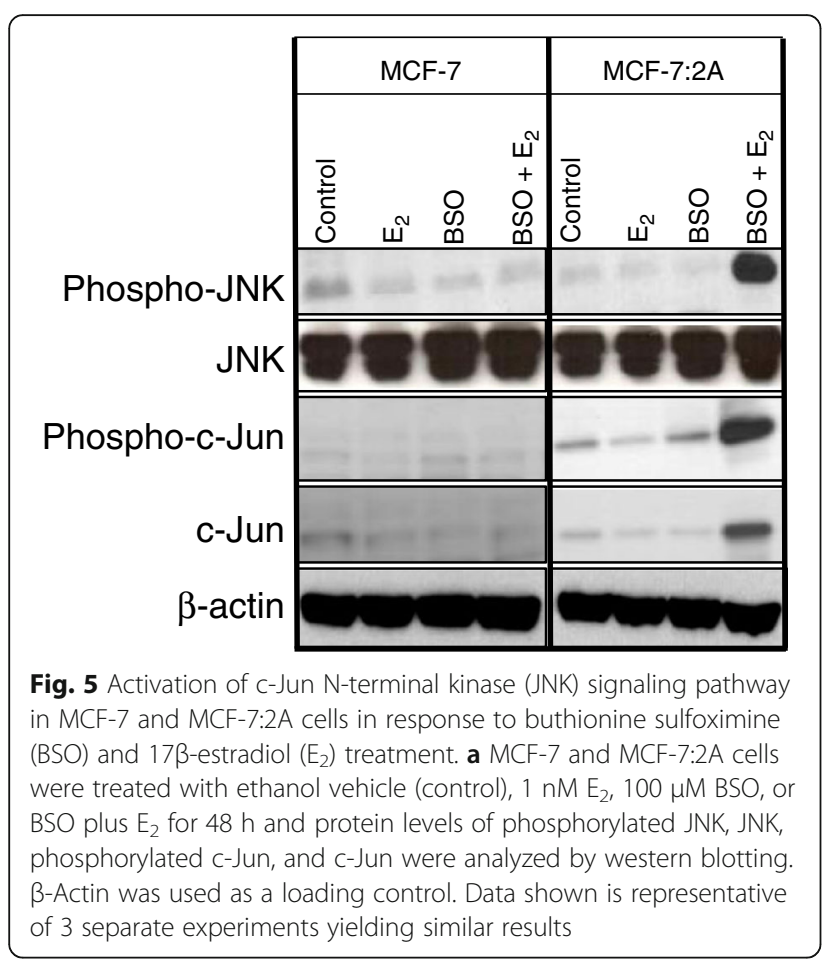

